\title{
Structure of the Atmosphere over South Polar and Equatorial Regions
}

\author{
By Parmjit Singh Sehra* \\ Physical Research Laboratory, Ahmedabad 380 009, India \\ (Manuscript received 17 September 1975, in revised form 15 December 1975)
}

\begin{abstract}
Average vertical profiles of zonal and meridional components of winds, and of temperatures as obtained from M-100 meteorological rocket soundings conducted at Molodezhnaya, Antarctica in January-February 1972 (southern summer) are compared with those of the corresponding ascents from Thumba, South India. The actual results are also compared with the Groves atmospheric model and the corresponding departures of the actuals from the Model are worked out. It is found that in the southern summer the polar tropopause and stratopause were about $27^{\circ} \mathrm{C}$ and $13^{\circ} \mathrm{C}$ warmer than the corresponding equatorial tropopause and stratopause, while the mesopause was about $25^{\circ} \mathrm{C}$ colder. At both the stations the zonal winds in the stratosphere were predominantly easterly in January with speed less than $50 \mathrm{~ms}^{-1}$, and westerly in February with speed less than $35 \mathrm{~ms}^{-1}$, while the meridional winds were variable. Zonal wind departures of the actuals from the Groves model were found to be in a range of about $\pm 35 \mathrm{~ms}^{-1}$, while the temperature departures were mostly negative by about $25^{\circ} \mathrm{C}$.
\end{abstract}

\section{Introduction}

Until 1960 synoptic investigations of the terrestrial atmosphere were confined to only balloon altitudes of about $30 \mathrm{~km}$. With the advent of the Meteorological Rocket Network (MRN) such analysis was extended to higher altitudes of about $80 \mathrm{~km}$. Such data are available for a large number of stations in the Northern Hemisphere. However, in the Southern Hemisphere there is a sparsity of rocket sounding stations due to which it is relatively less explored. The study of the atmospheric circulation around the South Pole is important since the weather and climate over the globe are strongly influenced by that circulation.

Under a joint Indo-Soviet agreement the author was the first Indian scientist to winter in Antarctica during the 17th Soviet Antarctic

\footnotetext{
* Also at:

Indian Space Research Organisation

Space Applications Centre

Remote Sensing and Meteorology Applications

Division

Ahmedabad, India.
}

Expedition, 1971-73. In particular, the author carried out meteorological rocket soundings of the upper atmosphere at the station Molodezhnaya, located at $67^{\circ} 40^{\prime} \mathrm{S}, 45^{\circ} 51^{\prime} \mathrm{E}$ at an altitude of $42 \mathrm{~m}$ above mean sea level in East Antarctica, Fig. 1. At the station there is a series of eastwest ridges made up of some exposed bed rocks where the ridges are separated by ice-filled valleys with elevations ranging from about 20 to $200 \mathrm{~m}$ along the coast. In a narrow zone about $10 \mathrm{~km}$ wide parallel to the coast exposed rock and soil are found in abundance which are, however, very rare inland. Although the station bed itself is confined to erratic and frostchurned mixed materials, yet nearby there are two outlet glaciers, Campbell and Hays, which form active moraines.

In 1972 the mean annual temperature observed at the station was $-10.5^{\circ} \mathrm{C}$ varying from a lowest minimum of $-35.8^{\circ} \mathrm{C}$ to a highest maximum of $7.0^{\circ} \mathrm{C}$. South-east winds prevailed over the surface with frequent gusts of 21 to $41 \mathrm{~ms}^{-1}$ speed. Annual mean relative humidity was $65 \%$ and the annual mean precipitation observed was $0.14 \mathrm{~cm}$. 


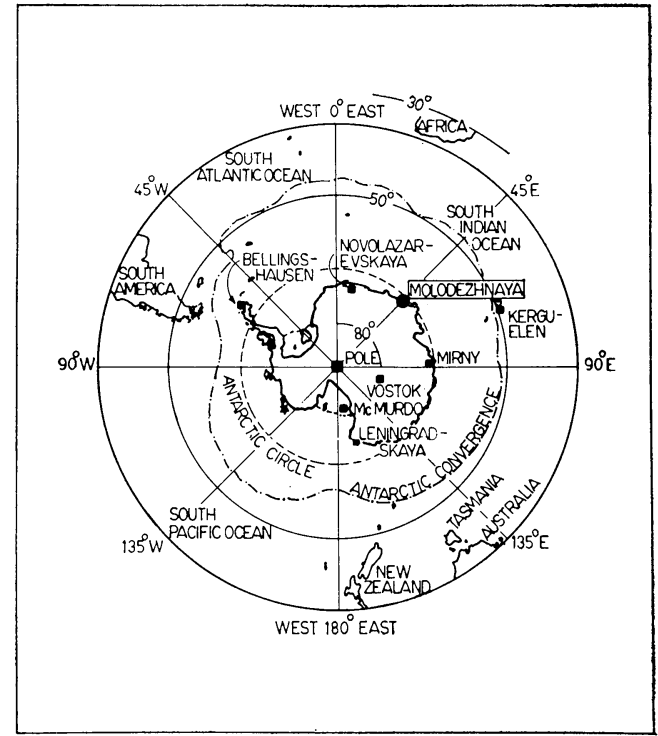

Fig. 1 Map of Antarctica showing the position of the station Molodezhnaya and surrounding area. Some of the other stations visited by the author while circumnavigating and trekking the Antarctic continent during his participation in the Soviet Antarctic Expedition in 197173 are also shown in the Map. Of particular interest was the visit and stay at 'Vostok', the earth's Geomagnetic South Pole which involved lot of trekking with sledge and footsore and was very strenuous.

Simultaneous M-100 meteorological rocket soundings were conducted weekly on all Wednesdays from Molodezhnaya, Antarctica and from Thumba $\left(8^{\circ} 32^{\prime} \mathrm{N}, 76^{\circ} 52^{\prime} \mathrm{E}\right)$, South India in 1972. This investigation is confined to January and February months of the southern summer. Average vertical profiles of zonal and meridional components of winds and of temperatures are studied and an intercomparison is made. A typical summer profile of January 26 is also discussed. The results are compared with the Groves atmospheric model (GROVES, 1971) and the corresponding departures of the actuals from the Model are worked out. Tropospheric, Stratospheric and Mesospheric circulation indices are computed using a method devised by WEBB (1964).

\section{Data acquisition}

For acquiring meteorological data of the upper atmosphere high altitude baloons and rockets are employed which incorporate a network of ground-borne and rocket-borne equipments. The objectives of the M-100 rocket system are to measure the meteorological parameters of the upper atmosphere up to an altitude of about $80 \mathrm{~km}$. It is a two stage rocket lifted by a solid propellant made of nitrocellulose up to about $95 \mathrm{~km}$. As the head part with the payload is separated on the ascending trajectory a parachute with a surface area of $35 \mathrm{~m}^{2}$ is opened. The instruments start measurement when the shielding device is thrown away after 60 seconds from the take off.

The head part consists of the probe with the temperature sensors and an instrument bay for the telemetry, transmitter, commutator, responder, power supply, and control unit. The telemetery transmitter on board the vehicle works at a frequency of $22150 \pm 100 \mathrm{kHz}$. The mechanical commutator provides scanning of 60 channels per cycle. A special super regenerative radio transponder working at a frequency of $1770-1795 \mathrm{MHz}$ is used. The payload incorporates 4 variable resistance thermometers made of 40 micron tungsten-rhenium wire connected in one arm of a balanced Wheatstone bridge. The radar data on the drift of the trajectory of the parachute, which gets completely filled around $60 \mathrm{~km}$ on the descending trajectory of the rocket, is used for measurement of the wind speed and direction. The ground telemetry consists of FM receiver with an input sensitivity of 2 micro volts. The transmitter signals are amplified in the receiver and are fed to the screen of a panoramic oscilloscope. The signals are photographed on a $35 \mathrm{~mm}$ film with the help of a cine-camera. During the complete flight the Meteor radar automatically tracks the rocket which is fitted with the transponder. The computers Minsk-2/IBM-360 finally process the data and apply all the necessary temperature and wind corrections using a standard programme written for this purpose.

\section{Analysis of data}

Winds up to an altitude of about $60 \mathrm{~km}$ are determined by measuring the drift of the parachute from the Meteor-1 radar position data and above $60 \mathrm{~km}$ by using an additional wind senior 'chaff'. In 1972, sixteen chaff-borne 
rocket flights were conducted from Molodezhnaya, Antarctica and none from Thumba, South India. Upper mesospheric wind results derived from the chaff flights have been discussed by the author in an earlier paper (SEHRA, 1974).

The temperature data are obtained from the variation in the resistance of the sensor coil using the relation

$$
R_{t}=R_{o}\left(1+\alpha t+\beta t^{2}\right)
$$

where $R_{t}$ is the resistance of the thermometer wire at temperature $t{ }^{\circ} \mathrm{C}$ and $R_{o}$ at $0^{\circ} \mathrm{C}$ and $\alpha$ and $\beta$ are the thermal factors of wire resistance. Temperature corrections for conductivity between the sensor wire and the insulating blocks, aerodynamic heating, thermal inertia of the thermometers, ohmic heating of the sensor wire and radiation from it, and heating due to long wave radiation are applied. In these measurements the random root mean square error in the determination of the temperature over the altitude region from 60 to $80 \mathrm{~km}$ does not ex- ceed 7 to $10^{\circ} \mathrm{C}$, at $50 \mathrm{~km}$ it is $5^{\circ} \mathrm{C}$, and below $40 \mathrm{~km}$ the error is less than $3^{\circ} \mathrm{C}$. In 1972 , more than sixty $\mathrm{M}-100$ meteorological rockets were launched from Molodezhnaya, Antarctica. The stratospheric and mesospheric temperature results derived from such flights are discussed by the author in another paper (SEHRA, 1975).

The vertical profiles of atmospheric winds and temperatures over. Molodezhnaya, Antarctica and Thumba, South India for the period JanuaryFebruary (southern summer) are drawn in Figs. 2 and 4 and a brief summary of the flights conducted is given in Table 1. Radiosonde data are used for completing the profiles in the lower atmosphere as each rocket flight was preceded by a standard radiosonde release. Figs. 2 and 4 show the monthly average profiles for January and February, while Fig. 3 represents a typical summer profile of January 26, 1972.

The actual results of the zonal winds and the temperatures in the altitude region from 25 to $85 \mathrm{~km}$ at an interval of $5 \mathrm{~km}$ are compared with the Groves atmospheric model (GROVES, 1971) and the corresponding departures of the ac-

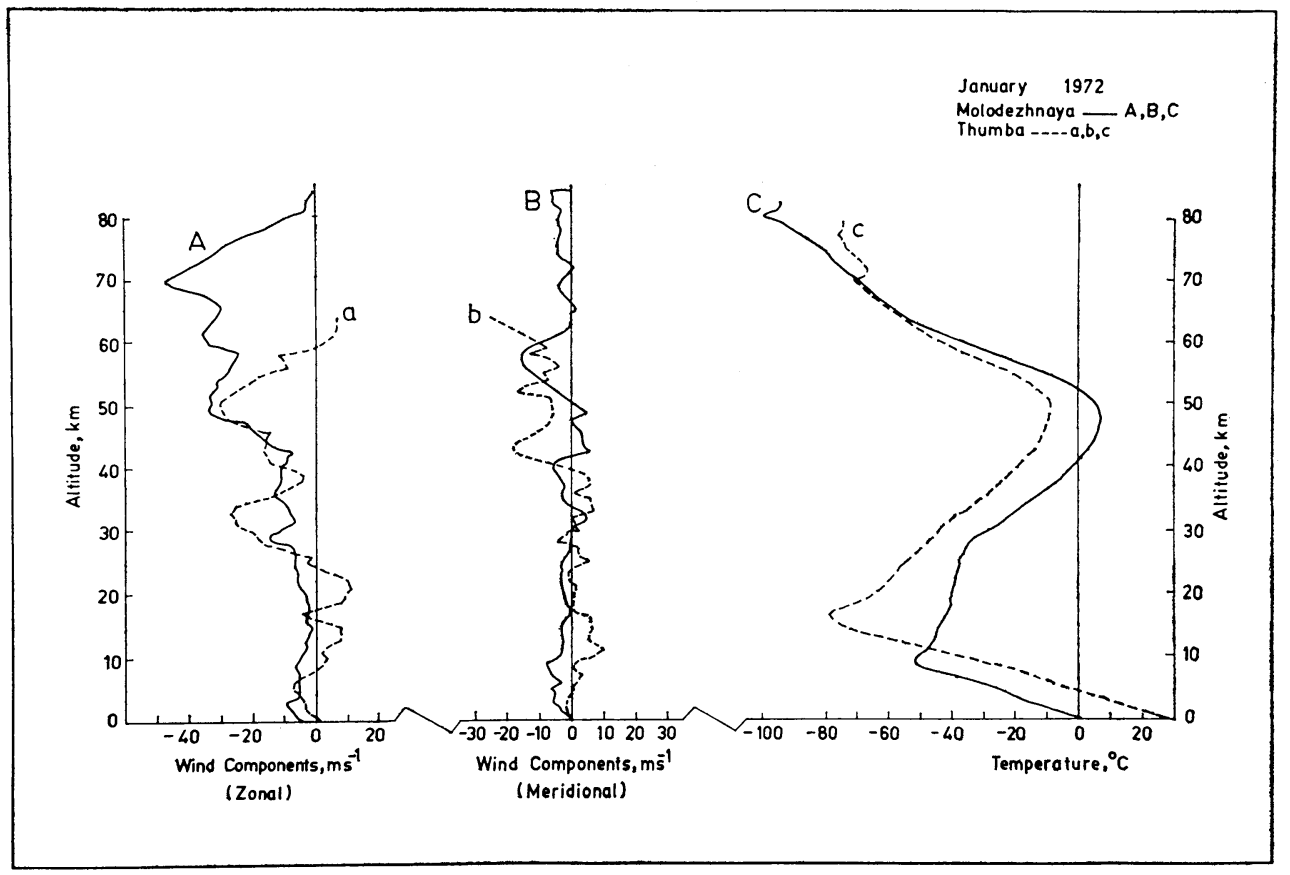

Fig. 2 Average vertical profiles of zonal winds (curves A, a), meridional winds (curves B, b) and temperatures (curves C, c) over Molodezhnaya, Antarctica (solid curves A, B, C) and Thumba, Equatorial India (dashed curves a, b, c) in January 1972. The curves (A, a) present zonal components of winds in $\mathrm{ms}^{-1}$, the curves $(\mathrm{B}, \mathrm{b})$ the meridional components of winds in $\mathrm{ms}^{-1}$, and the curves $(\mathrm{C}, \mathrm{c})$ the temperatures in ${ }^{\circ} \mathrm{C}$ over Molodezhnaya, Antarctica and Thumba, Equatorial India, respectively. 
tuals from the Model are drawn in Figs. 5 and 6 for January and February respectively. As the values in the Groves model apply to the first of each month, the Model average values are obtained from the data of two successive months for comparison. Thumba $\left(8^{\circ} 32^{\prime} \mathrm{N}\right)$ actuals for January are compared with the corresponding $10^{\circ} \mathrm{N}$ data of the Model. Since in the Model no data are available for $70^{\circ} \mathrm{S}$ station, actuals over Molodezhnaya $\left(67^{\circ} 40^{\prime} \mathrm{S}\right)$ for January are compared with $70^{\circ} \mathrm{N}$ data for July of the Groves Model and similarly for the February actuals with those for August of the Model, Figs. 5 and 6.

Tropospheric, Stratospheric and Mesospheric Circulation Indices (TsCI, SCI and $\mathrm{MsCI}$ ) are computed by using a method devised by WEBB (1964) and are given in Table 1.

\section{Results}

Various results derived from this investigation are given below:

\subsection{Zonal Winds}

From the solid curve (A) of Fig. 2 it is evident that average zonal wind components at Molodezhnaya, Antarctica in January 1972 were easterly throughout the atmosphere up to about $84 \mathrm{~km}$. In the troposphere the easterlies were weaker with speeds less than $10 \mathrm{~ms}^{-1}$. In the stratosphere the winds became stronger with speeds ranging from about 20 to $30 \mathrm{~ms}^{-1}$ around the stratopause. However, the wind maximum was found in the mesosphere at $70 \mathrm{~km}$ which had a speed of $47 \mathrm{~ms}^{-1}$. Above $70 \mathrm{~km}$ the easterly winds decreased with height having an average wind shear of about $0.004 \mathrm{~s}^{-1}$.

The corresponding average zonal wind profile of January for Thumba, South India given by the dashed curve (a) in Fig. 2 shows that up to about $7 \mathrm{~km}$ the winds were weak easterlies having speeds less than $7 \mathrm{~ms}^{-1}$. Around $7 \mathrm{~km}$ the zonal winds changed to weak westerlies of speeds less than $11 \mathrm{~ms}^{-1}$ with the maximum at $21 \mathrm{~km}$. From $25 \mathrm{~km}$ to $60 \mathrm{~km}$ the zonal winds were easterlies in toto, with speeds ranging from about 5 to 31 $\mathrm{ms}^{-1}$ having the maximum at $50 \mathrm{~km}$, the stratopause. However, about $60 \mathrm{~km}$ the zonal winds showed a westerly trend.

It is obvious from the solid curve (A) of the typical summer profile shown in Fig. 3 that on January 26, 1972, the zonal winds over Molodezhnaya, Antarctica were predominantly easterly in the atmosphere up to about $55 \mathrm{~km}$ altitude having a tropospheric maximum wind speed of $22 \mathrm{~ms}^{-1}$ at $3 \mathrm{~km}$ and a stratospheric maximum at $48 \mathrm{~km}$ with $43 \mathrm{~ms}^{-1}$ speed. In a narrow altitude region from 55 to $60 \mathrm{~km}$ westerly winds with speed ranging from 5 to $12 \mathrm{~ms}^{-1}$ were detected. In the mesosphere the winds were strong easter-

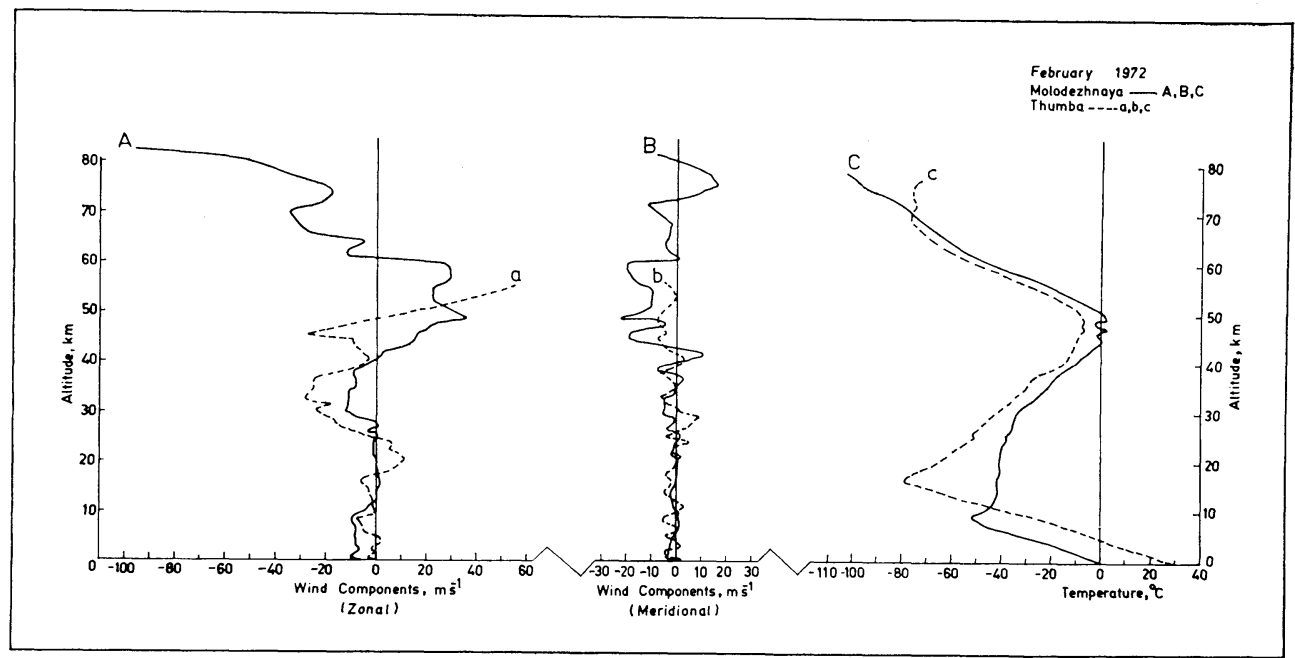

Fig. 3 Typical southern summer vertical profiles of zonal winds (curves A, a), meridional winds (curves $\mathrm{B}, \mathrm{b}$ ) and temperatures (curves $\mathrm{C}, \mathrm{c}$ ) over Molodezhnaya, Antarctica (solid curves A, B, C) and Thumba, Equatorial India (dashed curves a, b, c) on January 26, 1972. The curves (A, a) present zonal components of winds in $\mathrm{ms}^{-1}$, the curves $(\mathrm{B}, \mathrm{b})$ the meridional components of winds in $\mathrm{ms}^{-1}$ and the curves $(\mathrm{C}, \mathrm{c})$ the temperatures in ${ }^{\circ} \mathrm{C}$ over Molodezhnaya, Antarctica and Thumba, Equatorial India, respectively. 
lies having maximum speed of $47 \mathrm{~ms}^{-1}$ at $70 \mathrm{~km}$. However, in a narrow region from 78 to $85 \mathrm{~km}$ the easterly winds changed to westerlies with speeds ranging from about 5 to $13 \mathrm{~ms}^{-1}$ which again showed a reversal to easterlies above 85 $\mathrm{km}$.

The corresponding dashed curve (a) in Fig. 3 shows that on January 26 the zonal winds over Thumba, South India were weak and variable in the lower troposphere up to about $12 \mathrm{~km}$ altitude. And from 12 to $23 \mathrm{~km}$ the winds were mainly westerly with a maximum speed of 15 $\mathrm{ms}^{-1}$ at 15 and $22 \mathrm{~km}$ showing a sudden reversal at $17 \mathrm{~km}$, the tropopause. The lower stratospheric weak westerlies changed to strong easterly winds at about $24 \mathrm{~km}$ and persisted in the stratosphere up to $45 \mathrm{~km}$ with a maximum speed of $61 \mathrm{~ms}^{-1}$ at $42 \mathrm{~km}$ which showed a large wind shear. The stratospheric easterlies showed a reversal to westerlies at about $46 \mathrm{~km}$ which attained a maximum speed of $28 \mathrm{~ms}^{-1}$ at $49 \mathrm{~km}$, the approximate stratopause. The westerlies persisted in the lower mesosphere up to about $56 \mathrm{~km}$ and changed to easterly winds aloft.

Fig. 4 gives an average profile for February, 1972. The solid curve (A) in the figure shows that over Molodezhnaya, Antarctica the zonal winds were easterly with speeds iess than $10 \mathrm{~ms}^{-1}$ up to about $10 \mathrm{~km}$ and were weak and variable in an altitude range of about 10 to $30 \mathrm{~km}$. In the middle stratosphere, altitude region from 30 to $40 \mathrm{~km}$, easterly winds of speed about $10 \mathrm{~ms}^{-1}$ were detected which showed a reversal to strong westerly winds in the upper stratosphere with a maximum speed of $36 \mathrm{~ms}^{-1}$ at $49 \mathrm{~km}$, the approximate stratopause. The winds remained wasterly in the lower mesosphere up to $60 \mathrm{~km}$ with speeds in a range of 20 to $30 \mathrm{~ms}^{-1}$. A large wind shear of about $0.04 \mathrm{~s}^{-1}$ was detected around $60 \mathrm{~km}$ where the westerly winds showed a sudden reversal. The winds in the upper mesosphere were strong easterlies with speeds ranging from about 10 to $100 \mathrm{~ms}^{-1}$. Around 80 $\mathrm{km}$ there was a wind shear of $0.02 \mathrm{~s}^{-1}$ with a wind speed of $96 \mathrm{~ms}^{-1}$ at $82 \mathrm{~km}$.

The corresponding dashed curve (a) drawn in Fig. 4 shows that in February 1972 the zonal winds over Thumba, South India were predominantly weak easterly with speeds less than 10 $\mathrm{ms}^{-1}$ up to $17 \mathrm{~km}$, the tropopause where the weak easterlies showed a reversal to weak westerlies which again showed a reversal at $25 \mathrm{~km}$. Strong easterly winds persisted in the stratosphere from 26 to $49 \mathrm{~km}$ which attained a maximum speed of $28 \mathrm{~ms}^{-1}$ at $33 \mathrm{~km}$. The stratospheric easterlies showed a reversal at $49 \mathrm{~km}$, the stratopause, and changed into strong westerly winds with speeds ranging from about 10 to $50 \mathrm{~ms}^{-1}$ in the lower

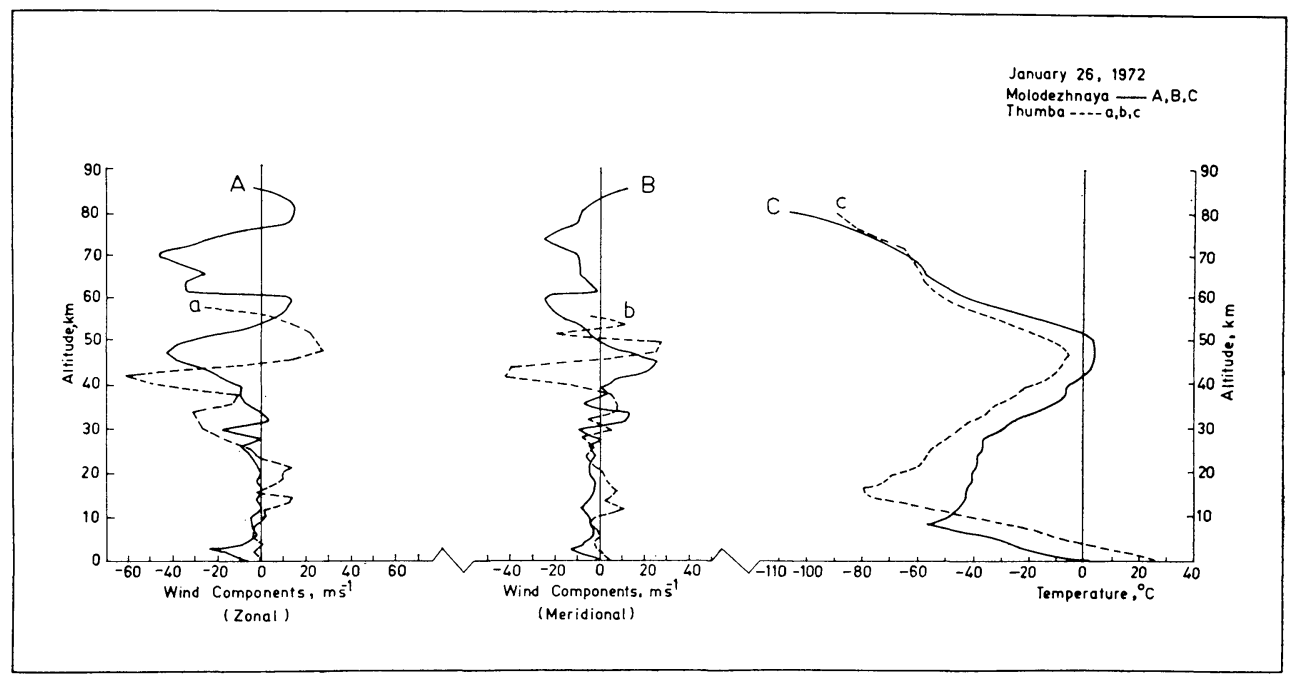

Fig. 4 Average vertical profiles of zonal winds (curves A, a), meridional winds (curves B, b) and temperatures (curves C, c) over Molodezhnaya, Antarctica (solid curves A, B, C) and Thumba, Equatorial India (dashed curves a, b, c) in February 1972. The curves (A, a) present zonal components of winds in $\mathrm{ms}^{-1}$, the curves $(\mathrm{B}, \mathrm{b})$ the meridional components of winds in $\mathrm{ms}^{-1}$, and the curves $(\mathrm{C}, \mathrm{c})$ the temperatures in ${ }^{\circ} \mathrm{C}$ over Molodezhnaya, Antarctica and Thumba, Equatorial India, respectively. 
mesosphere.

\subsection{Meridional Winds}

Average meridional wind profile, given by the solid curve (B) in Fig. 2, shows that in January the winds over Molodezhnaya, Antarctica were predominantly northerly up to the mesopause. $\mathrm{Up}$ to $30 \mathrm{~km}$ the northerlies were weak with speeds less than $8 \mathrm{~ms}^{-1}$. In the altitude region from 30 to $50 \mathrm{~km}$ the meridional components were weak and variable. In the 50 to $60 \mathrm{~km}$ region the northerlies were relatively stronger having a maximum speed of $16 \mathrm{~ms}^{-1}$ at $58 \mathrm{~km}$ which again became weaker in the upper mesosphere.

The corresponding average profile for Thumba given by the dashed curve (b) in Fig. 3 shows that in January the meridional winds over South India were weak and variable up to about 40 $\mathrm{km}$ with speeds less than $10 \mathrm{~ms}^{-1}$. Above $40 \mathrm{~km}$ the winds were predominantly northerly with speeds ranging from 5 to $25 \mathrm{~ms}^{-1}$.

The solid curve (B) in Fig. 3 shows that the meridional components of winds in the terrestrial atmosphere over Molodezhnaya, Antarctica on 26 January 1972 were weak northerly up to an altitude of $27 \mathrm{~km}$ with wind speed less than 8 $\mathrm{ms}^{-1}$. In an altitude region from 28 to $38 \mathrm{~km}$ the winds were variable with speed less than 20 $\mathrm{ms}^{-1}$. In the upper stratosphere, altitude region 38 to $50 \mathrm{~km}$, strong southerly winds were found which had a maximum speed of $26 \mathrm{~ms}^{-1}$ at 45 $\mathrm{km}$. The stratospheric southerlies changed to mesospheric northerlies at about $50 \mathrm{~km}$. In the mesosphere the northerly winds persisted up to $83 \mathrm{~km}$ having a maximum speed of $25 \mathrm{~ms}^{-1}$ at $74 \mathrm{~km}$ with a secondary maximum of $24 \mathrm{~ms}^{-1}$ at $60 \mathrm{~km}$. Above $83 \mathrm{~km}$ the profile showed a southerly trend.

From the corresponding dashed curve (b) in Fig. 3, it is obvious that the meridional winds over Thumba, South India on January 26 were variable with weaker winds of speeds less than $13 \mathrm{~ms}^{-1}$ up to $40 \mathrm{~km}$ and stronger winds aloft. In an altitude region from 40 to $45 \mathrm{~km}$ the meridional winds were strong northerlies which had a maximum speed of $47 \mathrm{~ms}^{-1}$ at $43 \mathrm{~km}$. The upper stratospheric northerly winds showed a reversal to southerlies around $46 \mathrm{~km}$ which had a maximum speed of $28 \mathrm{~ms}^{-1}$ at $49 \mathrm{~km}$. Above $50 \mathrm{~km}$ the meridional winds were again variable with speeds ranging from about 5 to $25 \mathrm{~ms}^{-1}$. Thus the upper stratosphere and the lower mesosphere were in a turbulent state having large wind shears with meridional winds rapidly shifting from northerlies to southerlies and vice versa.

The meridional wind components over Molodezhnaya, Antarctica in February 1972 are shown by the solid curve (B) in Fig. 4. Up to an altitude of $43 \mathrm{~km}$ the winds were weak and variable with speed less than $11 \mathrm{~ms}^{-1}$. Above 44 $\mathrm{km}$ the winds were predominantly northerly with a maximum speed of $23 \mathrm{~ms}^{-1}$ at $49 \mathrm{~km}$, the stratopause. The northerlies persisted up to 73 $\mathrm{km}$ in the mesosphere with a maximum speed of $20 \mathrm{~ms}^{-1}$ around $60 \mathrm{~km}$ which showed a reversal to southerly winds at $74 \mathrm{~km}$. The southerlies had wind speed ranging from 5 to $16 \mathrm{~ms}^{-1}$ in the upper mesosphere with the maximum at $76 \mathrm{~km}$. Above $80 \mathrm{~km}$ the winds showed a northerly trend.

The corresponding average profile of the meridional winds over Thumba, South India in February given by the dashed curve (b) in Fig. 4 shows that the winds were weak and variable up to $30 \mathrm{~km}$ with speeds less than $10 \mathrm{~ms}^{-1}$. Above $30 \mathrm{~km}$ the winds were predominantly weak northerlies in the upper stratosphere and the lower mesosphere.

\subsection{Temperatures}

Average temperature profile for January 1972 over Molodezhnaya, Antarctica given by the solid curve (C) in Fig. 2 shows that the polar tropopause was at $9 \mathrm{~km}$ altitude with air temperature of $-51.8^{\circ} \mathrm{C}$. The lapse rate in the troposphere was $-5.6^{\circ} \mathrm{C} \mathrm{km}^{-1}$. In an altitude region from 12 to $28 \mathrm{~km}$ a quasi-isothermal temperature structure prevailed with a lapse rate of $+0.5^{\circ} \mathrm{C} \mathrm{km}^{-1}$. In the upper stratosphere the lapse rate was about $2^{\circ} \mathrm{C} \mathrm{km}^{-1}$. The profile shows that the stratopause was at $47 \mathrm{~km}$ with a temperature of $6.5^{\circ} \mathrm{C}$. In the mesosphere the lapse rate was $-3.8^{\circ} \mathrm{C} \mathrm{km}^{-1}$ with the mesopause at $80 \mathrm{~km}$ having a temperature of $-99^{\circ} \mathrm{C}$.

The corresponding temperature profile for Thumba, South India is given by the dashed curve (c) in Fig. 2. It shows that in January the equatorial tropopause was at $17 \mathrm{~km}$ with a temperature of $-78.8^{\circ} \mathrm{C}$ and that the lapse rate in the troposphere was $-6.8^{\circ} \mathrm{C} \mathrm{km}^{-1}$. In the stratosphere the lapse rate was $+2.4^{\circ} \mathrm{C} \mathrm{km}^{-1}$ with the stratopause at $50 \mathrm{~km}$ having a temperature of $-8.8^{\circ} \mathrm{C} \mathrm{km}^{-1}$ and the mesopause was at $77 \mathrm{~km}$ with a temperature of $-77.5^{\circ} \mathrm{C}$.

The solid curve (C) in Fig. 3 is the typical southern summer profile of January 26, 1972 over Molodezhnaya, Antarctica. It shows that 
the polar tropopause and stratopause were at $9 \mathrm{~km}$ and $49 \mathrm{~km}$ altitudes with temperatures of $-56^{\circ} \mathrm{C}$ and $+4{ }^{\circ} \mathrm{C}$ respectively. The mesopause was however, not well defined.

The dashed curve (c), Fig. 3 is the corresponding profile of January 26 for Thumba, South India. It shows that the equatorial tropopause and stratopause were at $17 \mathrm{~km}$ and $48 \mathrm{~km}$ with temperatures of $-79^{\circ} \mathrm{C}$ and $-7^{\circ} \mathrm{C}$ respectively, while the mesopause was not well defined.

The solid curve (C) in Fig. 4 gives an average temperature profile for February 1972 over Molodezhnaya, Antarctica. It shows that the polar tropopause and stratopause in late summer were at $9 \mathrm{~km}$ and $49 \mathrm{~km}$ with temperatures of $-52.3^{\circ} \mathrm{C}$ and $2.0^{\circ} \mathrm{C}$ respectively while the mesopause was not well defined. Temperature lapse rates in the troposphere, upper stratosphere, and mesosphere were $-5.5,+2.4$ and $-3.4^{\circ} \mathrm{C}$ $\mathrm{km}^{-1}$ respectively, while in an altitude region from 12 to $28 \mathrm{~km}$ the lapse rate was very small, $+0.4^{\circ} \mathrm{C} \mathrm{km}^{-1}$ showing that the lower strato- phere was in a quasi-isothermal state.

(The dashed curve (c) in Fig. 4 gives the corresponding temperature profile of February for the station Thumba, South India. It shows that in late summer the equatorial tropopause and stratopause were at $16 \mathrm{~km}$ and $49 \mathrm{~km}$ with temperatures of $-79.3^{\circ} \mathrm{C}$ and $-7.3^{\circ} \mathrm{C}$ respectively. The mesopause was found in an altitude region from 70 to $75 \mathrm{~km}$ having a minimum temperature of $-77.0^{\circ} \mathrm{C}$ at $70 \mathrm{~km}$ with a secondary minimum of $-76.5^{\circ} \mathrm{C}$ at $75 \mathrm{~km}$. Temperature lapse rates in the troposphere, stratosphere and mesosphere were $-7.2,+2.4$ and $-4.3^{\circ} \mathrm{C} \mathrm{km}^{-1}$ respectively.

\section{Comparison with the Groves atmospheric model}

The above results viz. zonal winds and temperatures are compared with the Groves atmospheric model (GROVES, 1971) and their departures from the Model for the months of January and February are shown in Figs. 5 and 6 respec-

January 1972
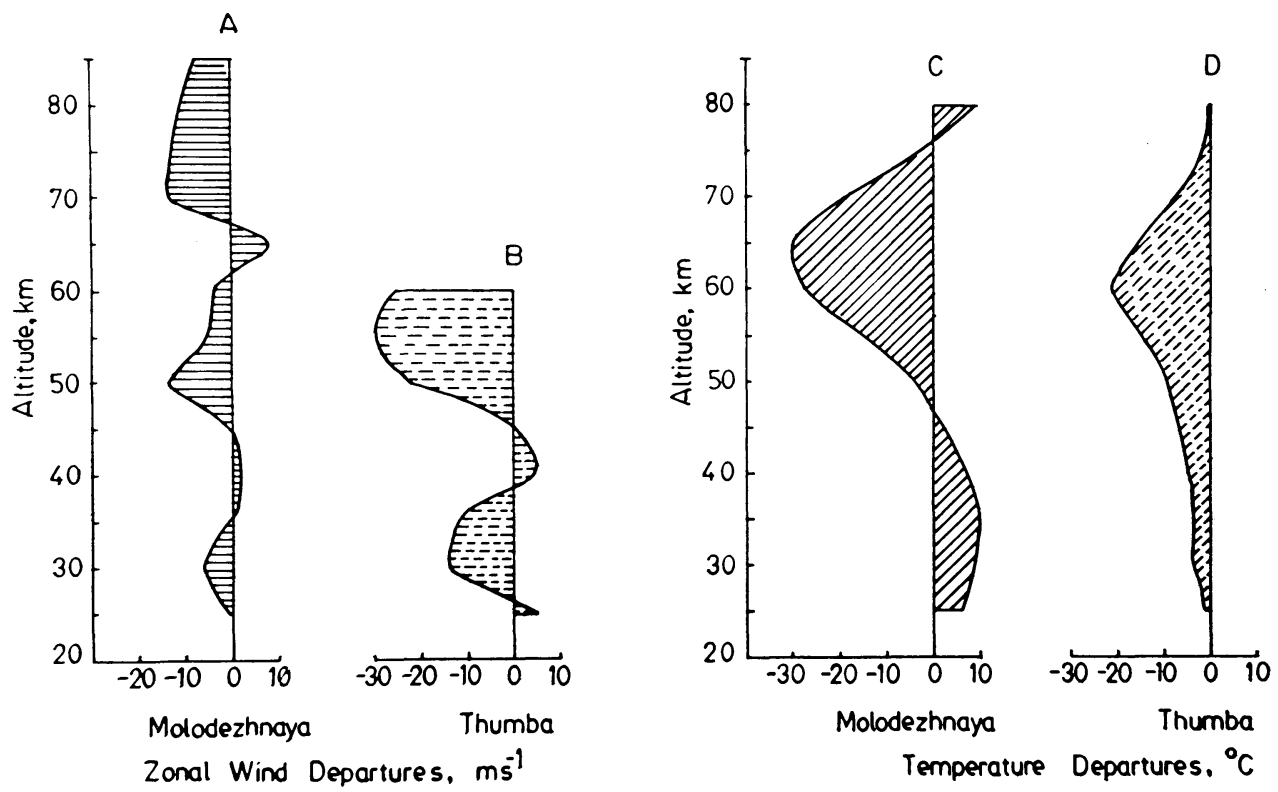

Fig. 5 Departures of the actual zonal wind and temperature results from the Groves atmospheric model over Molodezhnaya, Antarctica, (curves A, C) and Thumba, Equatorial India (curves B, D) in January 1972. Zonal wind departures in $\mathrm{ms}^{-1}$ are given by the curves shaded with horizontal lines (solid curve A for Molodezhnaya and dashed curve B for Thumba), while the temperature departures in ${ }^{\circ} \mathrm{C}$ are given by the curves shaded with inclined lines (solid curve $\mathrm{C}$ for Molodezhnaya and dashed curve $\mathrm{D}$ for Thumba). 
tively. Comparison is made for the altitude region from 25 to $85 \mathrm{~km}$ at an interval of $5 \mathrm{~km}$.

\subsection{Zonal wind departures}

The curve (A) in Fig. 5 represents departures of the actual zonal winds at Molodezhnaya (about $68^{\circ} \mathrm{S}$ ), Antarctica in January from the corresponding Groves profiles at $70^{\circ} \mathrm{N}$ in July. The departures were less than $14 \mathrm{~ms}^{-1}$ in the stratosphere and there was a fairly good agreement between the two in the altitude region from 25 to $45 \mathrm{~km}$. The winds were predominantly easterly in both, the actual profile and the Groves profile. Maximum departure from the Model was $-23.5 \mathrm{~ms}^{-1}$ at $50 \mathrm{~km}$ with a wind speed of $34 \mathrm{~ms}^{-1}$ at Molodezhnaya and $20.5 \mathrm{~ms}^{-1}$ at $70^{\circ} \mathrm{N}$ (from the Groves model). The negative departures in the figure show that the actual easterly winds were stronger than the Model easterlies, while the positive departures show the reverse.

The curve (B) in Fig. 5 gives the zonal wind departures of the actuals over Thumba (about $9^{\circ} \mathrm{N}$ ), South India from the Groves model profiles (at $10^{\circ} \mathrm{N}$ ) in January. It shows that in
January the zonal wind departures in the stratosphere and the lower mesosphere were less than $30 \mathrm{~ms}^{-1}$. The winds in the stratosphere were easterly with a westerly trend in the lower mesosphere in both the profiles, actual as well as Groves. Again, the negative departures mean that the Thumba zonal winds were stronger than the Model winds. However, at $60 \mathrm{~km}$ where the westerlies prevailed, the Thumba winds were weaker having a speed of $2.5 \mathrm{~ms}^{-1}$ and the departure from the Groves model was $-25 \mathrm{~ms}^{-1}$. Good agreement was found around $40 \mathrm{~km}$ where the departures were less than $+4.7 \mathrm{~ms}^{-1}$ showing that the Groves easterlies were somewhat stronger than the actual Thumba easterlies.

The curve (A) in Fig. 6 gives the zonal wind departures of the Molodezhnaya actuals from the Groves model for February 1972. In the Groves profile the winds are predominantly easterly in the stratosphere and the mososphere, while in the actual profile the winds were predominantly strong westerly in an altitude region from about 45 to $60 \mathrm{~km}$ which contributed to larger departures in this region with a maximum of $+35.5 \mathrm{~ms}^{-1}$ at $50 \mathrm{~km}$ and a secondary maxi-
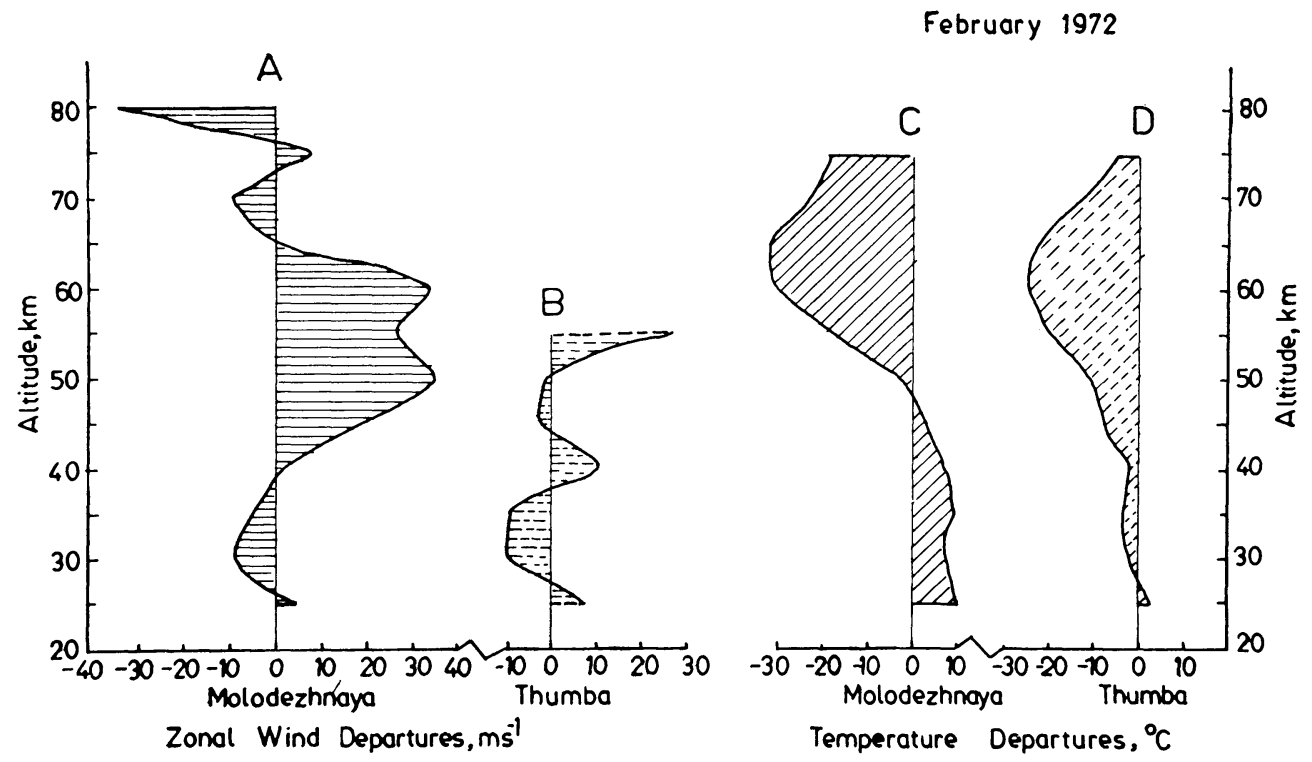

Fig. 6 Departures of the actual zonal wind and temperature results from the Groves atmospheric model over Molodezhnaya, Antarctica (curves A, C) and Thumba, Equatorial India (curves B, D) in February 1972. Zonal wind departures in $\mathrm{ms}^{-1}$ are given by the curves shaded with horizontal lines (solid curve A for Molodezhnaya and dashed curve B for Thumba), while the temperature departures in ${ }^{\circ} \mathrm{C}$ are given by the curves shaded with inclined lines (solid curve $\mathrm{C}$ for Molodezhnaya and dashed curve D for Thumba). 
mum of $+34.0 \mathrm{~ms}^{-1}$ at $60 \mathrm{~km}$. The negative departures in the figure show that the actual easterly winds over Molodezhnaya, Antarctica were stronger than the corresponding Groves winds.

The corresponding zonal wind departures of the Thumba actuals from the Model for February are shown by the curve (B) in Fig. 6. The winds were predominantly easterly in the stratosphere with strong westerlies aloft, in both the actual and the Model profiles. Maximum departure was $+26.5 \mathrm{~ms}^{-1}$ at $55 \mathrm{~km}$ with strong westerlies of $50.5 \mathrm{~ms}^{-1}$ at Thumba and $24.0 \mathrm{~ms}^{-1}$ from the Groves model. A good agreement between the actuals and the Model was found around the stratopause in an altitude region from 45 to 50 $\mathrm{km}$ with departures of about $-2 \mathrm{~ms}^{-1}$. Again, the negative deviations from the Model mean that the actuals were stronger than the Model winds, while the positive departures mean the reverse.

\subsection{Temperature departures}

The curve (C) in Fig. 5 gives temperature departures of the Molodezhnaya actuals from the Groves atmospheric model for January 1972. In the stratosphere the deviations from the Model were less than $+10^{\circ} \mathrm{C}$. Maximum departure was $-30^{\circ} \mathrm{C}$ at $65 \mathrm{~km}$ and the minimum was $+1.8^{\circ} \mathrm{C}$ at $45 \mathrm{~km}$ around the stratopause. Positive departures in the Figure show that the actual temperatures were greater than the Groves temperatures, while the negative departures mean the reverse. It is thus obvious from the Figure that in January the stratosphere over Molodezhnaya, Antarctica is warmer than the corresponding Groves profile with a maximum of $10^{\circ} \mathrm{C}$ at 35 $\mathrm{km}$, while the Molodezhnaya mesosphere is colder than the Model with a maximum of $30^{\circ} \mathrm{C}$ at 65 $\mathrm{km}$. However, at $80 \mathrm{~km}$ around the mesopause the Molodezhnaya profile is about $8.5^{\circ} \mathrm{C}$ warmer than the Groves profile.

The corresponding temperature departures of the Thumba actuals from the Model for January are shown by the curve (D) in Fig. 5. Sufficiently good agreement between the actuals and the Model was found in the stratosphere with departures ranging from -1 to $-9^{\circ} \mathrm{C}$. The maximum departure was $-21.8^{\circ} \mathrm{C}$ at $60 \mathrm{~km}$. Negative departures in the Figure mean that the actual temperatures over Thumba, South India were colder than the corresponding Groves model temperatures.

The curve (C) in Fig. 6 gives the temperature departures over Molodezhnaya, Antarctica from the Groves model for February 1972. Again, in the stratosphere the actual temperatures were warmer than the Groves temperatures with a maximum of $9.8^{\circ} \mathrm{C}$ at $25 \mathrm{~km}$, while in the mesosphere the actuals were colder with a maximum of $31.8^{\circ} \mathrm{C}$ at $65 \mathrm{~km}$.

The corresponding temperature departures of the Thumba actuals from the Model for February are shown by the curve (D) in Fig. 6 . It is obvious from the Figure that in February the Thumba actuals were colder than the corresponding Groves profile with a maximum of $24.8^{\circ} \mathrm{C}$ at $60 \mathrm{~km}$. There is sufficiently good agreement between the two in the stratosphere with departures ranging from about $-2{ }^{\circ} \mathrm{C}$ to $-10^{\circ} \mathrm{C}$.

From Figs. 5 and 6 it is obvious that the temperature departures of the actuals from the Model in January had a good similarity with those in February both for Molodezhnaya, Antarctica and Thumba, South India. However, the zonal wind departures were different in the two cases.

\section{Atmospheric circulation indices}

WEBB (1964) devised a method for studying reversal of winds at different times during a year by calculating an average flow over a layer 10 $\mathrm{km}$ thick from 45 to $55 \mathrm{~km}$ centred at $50 \mathrm{~km}$ and called it the Stratospheric Circulation Index (SCI) of the appropriate layer. Using the same method average values of the wind speeds for the layers from 5 to $15 \mathrm{~km}, 10$ to $20 \mathrm{~km}, 45$ to $55 \mathrm{~km}$ and 70 to $80 \mathrm{~km}$ are computed for deriving from the individual soundings Tropospheric Circulation Index (TsCI), Stratospheric Circulation Index (SCI) and Mesospheric Circulation Index $(\mathrm{MsCI})$ of the appropriate layers. Average winds over the layer from 5 to $15 \mathrm{~km}$ give TsCI for Molodezhnaya, Antarctica, while those from 10 to $20 \mathrm{~km}$ give TsCI for Thumba, South India. This is because the polar tropopause was found to be at $9 \mathrm{~km}$, while the equatorial tropopause was at $17 \mathrm{~km}$. Average winds over the layers from 45 to $55 \mathrm{~km}$ and from 70 to $80 \mathrm{~km}$ give the corresponding SCI and MsCI. The Tropospheric, Stratospheric and Mesospheric Circulation Indices computed for January-February 1972 are given in Table-1. Positive values of the Circulation Indices refer to flow from the south for the meridional winds and to flow from the west for the zonal winds, while the negative values present flows from the north and from the east correspondingly. 


\subsection{Tropospheric Circulation Index (TsCI)}

Table- 1 shows that the meridional components of the Tropospheric Circulation Index over Molodezhnaya, Antarctica were predominantly northerly in January and February (southern summer) with a maximum wind speed of $7.6 \mathrm{~ms}^{-1}$ on January 12. However, a wind reversal from weak northerlies to weak southerlies of speed $8.9 \mathrm{~ms}^{-1}$ occurred from January 26 to February 2 which again changed to weak northerlies by February 16. The corresponding meridional TsCI over Thumba, South India was weak southerly in January with a maximum wind speed of $5.7 \mathrm{~ms}^{-1}$ on January 19. The weak southerlies showed a reversal to weak northerlies from January 26 to February 2 which then persisted throughout the month. January 26 to February 2 thus seems to be a transition period for the meridional winds in the troposphere over Antarctica and South India.

The zonal components of the Tropospheric
Circulation Index over Molodezhnaya, Antarctica in January-February were predominantly easterly having a maximum wind speed of 10.8 $\mathrm{ms}^{-1}$ on February 23 with a secondary maximum of $9 \mathrm{~ms}^{-1}$ on January 19 . However, a wind reversal occurred around February 16 when the zonal flow became westerly with a speed of 6 $\mathrm{ms}^{-1}$. The corresponding zonal $\mathrm{TsCI}$ at Thumba, South India was predominantly westerly in January with a maximum wind speed of $8.5 \mathrm{~ms}^{-1}$ on January 19. The westerlies changed to weak easterlies during the 1st half of February which persisted later. Thus there seems to be a transition of the zonal winds both over Antarctica and South India around mid February.

\subsection{Stratospheric Circulation Index (SCI)}

Meridional and zonal components of the Stratospheric Circulation Index over Molodezhnaya, Antarctica and Thumba, South India for the period from January to February (southern summer) are given in Table 1.

Table 1 Summary of the M-100 meterological rocket soundings conducted from (i) Molodezhnaya, Antarctica and (ii) Thumba, South India in January-February 1972

\begin{tabular}{|c|c|c|c|c|c|c|c|c|c|c|}
\hline \multirow[t]{2}{*}{ Station } & \multirow[t]{2}{*}{ Date } & \multirow[t]{2}{*}{$\begin{array}{l}\text { Time } \\
(\mathrm{GMT})\end{array}$} & \multirow{2}{*}{$\begin{array}{l}\text { Wind } \\
\text { track } \\
(\mathrm{km})\end{array}$} & \multirow{2}{*}{$\begin{array}{c}\text { Temper- } \\
\text { ature } \\
\text { track } \\
(\mathrm{km})\end{array}$} & \multicolumn{2}{|c|}{$\begin{array}{l}\text { (i) } 5-15 \mathrm{~km} \\
\text { (ii) } 10-20 \mathrm{~km} \\
\text { TsCI }\left(\mathrm{ms}^{-1}\right)\end{array}$} & \multicolumn{2}{|c|}{$\begin{array}{l}45-55 \mathrm{~km}^{-1} \\
\mathrm{SCI}\left(\mathrm{ms}^{-1}\right)\end{array}$} & \multicolumn{2}{|c|}{$\begin{array}{c}\left.70-80 \mathrm{~km}^{-1}\right) \\
\operatorname{MsCI}\left(\mathrm{ms}^{-1}\right)\end{array}$} \\
\hline & & & & & Meridional & Zonal & Meridional & Zonal & $\overline{\text { Meridional }}$ & 1 Zonal \\
\hline Iolodzhnaya & Jan. 5 & 1450 & $80-10$ & $82-10$ & -0.8 & -1.7 & -1.3 & -35.6 & 2.4 & -41.5 \\
\hline Thumba & Jan. 5 & 1433 & $55-10$ & & 0.7 & -1.1 & -32.5 & -49.6 & $\mathrm{~N} / \mathrm{A}$ & $\mathrm{N} / \mathrm{A}$ \\
\hline Molodezh & Jan. 12 & 1425 & $48-10$ & 78 & -7.6 & -4.0 & N/A & N/A & $\mathrm{N} / \mathrm{A}$ & N/A \\
\hline humba & Jan. 12 & 1430 & $64-10$ & & 5.1 & 2.7 & -42.5 & -34.2 & $\mathrm{~N} / \mathrm{A}$ & $\mathrm{N} / \mathrm{A}$ \\
\hline Molodezhnaya & Jan. 19 & 1440 & $\begin{array}{l}(84-62) \\
(43-10)\end{array}$ & & -4.1 & -9.0 & N/A & N/A & 5.5 & -29.3 \\
\hline humba & Jan. 19 & 1431 & $65-10$ & & 5.7 & 8.5 & 29.6 & -34.3 & N/A & N/A \\
\hline Aolo & Jan. 26 & 1435 & $86-10$ & & -5.0 & -2.7 & 2.1 & -26 & -16.4 & -13.1 \\
\hline Chun & Jan. 26 & 1655 & -25 & & 3.9 & 6.6 & 10.1 & 20.7 & N/A & N/A \\
\hline Molodezhnaya & Feb. 2 & 1448 & $48-10$ & & 8.9 & -5.8 & $\mathrm{~N} / \mathrm{A}$ & $\mathrm{N} / \mathrm{A}$ & $\mathrm{N} / \mathrm{A}$ & $\mathrm{N} / \mathrm{A}$ \\
\hline Thumba & Feb. 2 & 1430 & $45-10$ & & -2.4 & 2.0 & $\mathrm{~N} / \mathrm{A}$ & N/A & N/A & N/A \\
\hline Molodezhnaya & Feb. 16 & 1535 & $82-10$ & $76-10$ & -5.1 & 6.0 & -19.1 & 27.8 & 5.1 & -30.5 \\
\hline Thumba & Feb. 17 & 1430 & $56-10$ & $77-10$ & -2.5 & -2.5 & 1.2 & 6.4 & $\mathbf{N} / \mathbf{A}$ & N/A \\
\hline Molodezhnaya & Feb. 23 & 1530 & $55-10$ & $73-10$ & -4.5 & -10.8 & -21.6 & 33.8 & N/A & N/A \\
\hline Thumba & Feb. 23 & 1430 & $56-24$ & $77-24$ & -0.1 & -0.2 & -8.5 & 18.1 & N/A & N/A \\
\hline
\end{tabular}

The Table shows that the meridional SCI over Molodezhnaya, Antarctica was predominantly northerly with a maximum wind speed of 21.6 $\mathrm{ms}^{-1}$ on February 23. However, a weak southerly trend with a wind speed of about $2 \mathrm{~ms}^{-1}$ occurred on January 26. The corresponding meridional SCI over Thumba, South India was found to be variable during January to February with a strong northerly flow of maximum speed $42.5 \mathrm{~ms}^{-1}$ on January 12 and a strong southerly flow of speed $29.6 \mathrm{~ms}^{-1}$ on January 19 . The southerly flow persisted till about mid February and again became northerly around February 23.

The zonal SCI over Antarctica was found to 
be predominantly easterly in January with a maximum wind speed of $35.6 \mathrm{~ms}^{-1}$ on January 5 , and westerly during February with a maximum speed of $33.8 \mathrm{~ms}^{-1}$ on February 23. Wind reversal occurred sometime during January 26 to February 16. The corresponding zonal SCI over South India also showed a strong easterly flow in January with a maximum wind speed of 49.6 $\mathrm{ms}^{-1}$ on January 5, and a westerly flow in February.

The reversal of zonal winds from strong easterlies to relatively weaker westerlies occurred during January 19 to January 26. The westerly flow had a maximum speed of $20.7 \mathrm{~ms}^{-1}$ on January 26.

\subsection{Mesospheric Circulation Index (MsCI)}

Table 1 gives Mesospheric Circulation Index over Molodezhnaya, Antarctica for only those days in January-February 1972 when special chaff-borne M-100 meteorological rocket flights were conducted. The Table shows that the mesospheric meridional flow was predominantly weak southerly with a reversal to northerlies of speed $16.4 \mathrm{~ms}^{-1}$ on January 26 , while the zonal flow was strong easterly which had a maximum speed of $41.5 \mathrm{~ms}^{-1}$ on January 5 with a secondary maximum of $30.5 \mathrm{~ms}^{-1}$ on February 16. A detailed account of the mesospheric winds in Antarctica has been discussed by the author in an earlier paper (SEHRA, 1974).

Since no 'chaff' flights were conducted from Thumba, South India in January-February, no $\mathrm{MsCI}$ is available for this equotorial station. $\mathrm{N} / \mathrm{A}$ in the Table means not available.

\section{Discussions and conclusions}

Some of the important conclusions that can be drawn from this investigation are discussed below:

7.1 The atmospheric zonal winds in the southern hemisphere over Antarctica were predominantly easterly in the southern summer. However, there was a marked wind reversal from easterlies to westerlies at 40 to $60 \mathrm{~km}$ altitude between January and February, while the winds at the northern high latitudes in summer are known to be notably steady. The zonal winds over Equatorial India were mostly easterly in the upper atmosphere above $25 \mathrm{~km}$ in JanuaryFebruary with a pronounced westerly trend between 45 and $55 \mathrm{~km}$ on January 26. The meridional winds both over the South Polar and the Equatorial regions were variable.
7.2 A remarkable wave like structure was detected in the vertical profiles of wind components both over the South Polar and the Equatorial regions. These observations indicate that the recurrent wave structure might have been caused by the wind fluctuations due to atmospheric gravity waves. It is also obvious from the Figures 2 to 4 that these irregular waves were predominantly horizontal, had amplitudes that increased with height and also the dominant scale size of the vertical wave length increased with height which may be explained in terms of gravity waves. The amplitude of the irregular waves increased rapidly with height owing to the rapid decrease in atmospheric density. Another process going on simultaneously may be turbulent motions causing the irregular waves over rough terrain, about local circulations such as clouds which as a result of local instabilities can be expected to make their influence felt at remote points in the atmosphere. Thus it appears that both the processes i.e. inetrnal manifestations in the wind field due to atmospheric gravity waves and irregular fluctuations set up due to turbulent motions might cause the wave like structures in the vertical wind profiles.

7.3 From the combined average values of the seven meteorological ' $\mathrm{M}-100$ ' rocket soundings conducted at Molodezhnaya in JanuaryFebruary 1972, it is found that in the southern summer the Antarctic tropopause and stratopause were located at $9 \mathrm{~km}$ and $47 \mathrm{~km}$ having temperatures $-52.1{ }^{\circ} \mathrm{C}$ and $4.3^{\circ} \mathrm{C}$, while the equatorial tropopause and stratopause were at altitudes $17 \mathrm{~km}$ and $49 \mathrm{~km}$ with temperatures $-78.6^{\circ} \mathrm{C}$ and $-8.2^{\circ} \mathrm{C}$, respectively. From the meagre upper mesospheric data, the south polar and the equatorial mesopause were apparently found around $80 \mathrm{~km}$ and $75 \mathrm{~km}$ with temperatures of about $-100^{\circ} \mathrm{C}$ and $-75^{\circ} \mathrm{C}$. During January-February average temperature lapse rates in the troposphere, stratosphere and mesosphere over Antarctica were about -5.5, +2.2 and $-3.6^{\circ} \mathrm{C} \mathrm{km}^{-1}$, while over the equator the corresponding lapse rates were about -7.0 , +2.4 and $-4.0^{\circ} \mathrm{C} \mathrm{km}^{-1}$. In an altitude region from 12 to $28 \mathrm{~km}$ the temperature structure over Antarctica was found to be quasi-isothermal with a lapse rate of $+0.4^{\circ} \mathrm{C} \mathrm{km}^{-1}$.

7.4 The summer polar tropopause and stratopause in the southern hemisphere over Antarctica were found to be about $27^{\circ} \mathrm{C}$ and $13^{\circ} \mathrm{C}$ warmer than the corresponding equatorial 
tropopause and stratopause while the Antarctic mesopause was apparently about $25^{\circ} \mathrm{C}$ colder. Also, the south polar tropopause and stratopause were located at altitudes about $8 \mathrm{~km}$ and $2 \mathrm{~km}$ lower than their corresponding equatorial counterparts while the Antarctic mesopause seemed to be located at an altitude about $5 \mathrm{~km}$ higher than the corresponding equatorial mesopause in the southern summer. The primary reason of the warmer polar tropopause and stratopause is the availability of more solar radiation in Antarctica due to almost continuous sunlight there in summer. Furthermore, in Antarctica there is less convection which forms the tropopause at a lower altitude around $9 \mathrm{~km}$. Since the tropospheric temperature lapse rate extends over a smaller altitude range the polar tropopause becomes warmer as compared with the equatorial tropopause which is located at a higher altitude around $17 \mathrm{~km}$ as a consequence of greater degree of convection at the equator.

Again, in the southern summer the Antarctic stratosphere receives more solar radiation almost continuously which penetrates into it perhaps to a greater depth (lower altitude) where the ultraviolet radiation gets absorbed by ozone. Apparently, in the southern summer the ozone maximum may be at lower level where there is maximum absorption thus heating the stratosphere and forming the stratopause at a lower altitude and with a warmer temperature as compared with its equatorial counterpart. The summer polar mesopause in the southern hemisphere may be colder than its equatorial counterpart due to strong adiabatic cooling in the Antarctic mesophere. It is because upward motions exist to some degree in summer polar areas due to the expansion of stratospheric regions. Initial phases of upward motions of this meridional current at the stratopause could well be supported by ozone heating in that region. As the air lifts toward the mesopause, adiabatic cooling would become a very strong effect and consequently the polar mesopause becomes colder and also shifted somewhat upwards.

7.5 Departures of the actual zonal winds from the corresponding Groves atmospheric model over Antactica varied from -14 to +8 $\mathrm{ms}^{-1}$ in January and -34 to $+36 \mathrm{~ms}^{-1}$ in February while the corresponding equatorial departures ranged from -30 to $+5 \mathrm{~ms}^{-1}$ and -9 to $+27 \mathrm{~ms}^{-1}$ between the two months. The atmospheric temperature departures of the actuals from the Groves profiles varied -30 to $+10^{\circ} \mathrm{C}$ over the south polar region and from -25 to $+2{ }^{\circ} \mathrm{C}$, over the equatorial region in the southern summer.

The departures over Antarctica are apparently because the Groves atmospheric model is based on the data from the northern hemisphere which differs from the southern hemisphere in many respects. Antarctica is as continental as the Arctic at the surface, but the dominant water surface outside the polar regions in the southern hemisphere and the extensive areas of land surrounding the Arctic emerge as the important factors controlling various changes in the atmospheric winds and temperatures in the southern and the northern hemispheres. The higher albedo over Antarctica than over the Arctic explains the much lower summer temperatures of the Antarctic. The coldness of the air at middle southern latitudes in summer, compared with the same northern latitudes, owes more to the physical properties of the immense southern oceans than to the presence of an ice-covered polar continent. The departures may also be due to the reasons that the southern hemisphere is more symmetric and has a vigorous general circulation and that the Antarctic continent is located at a higher elevation than the Arctic. Likewise for the Thumba latitude in the eastern hemisphere, the Groves Model is based on data from all longitudes mostly from the western hemisphere. Departures of the equatorial actuals from the Groves profiles may, therefore, be the evidence of longitudinal asymmetries between the eastern and the western hemispheres. Thus the discrepancy between the actuals and the Groves Model may be largely attributed to the specificity of geographical locations of the two stations Molodezhnaya, Antarctica and Thumba, Equatorial India.

In conclusion, it is very necessary to collect more and more meteorological rocketsonde data particularly in the relatively less explored Southern Hemisphere in order to better understand the physical processes influencing the weather and climate all over the globe.

\section{Acknowledgements}

The author acknowledges the collaboration of the members of the Soviet Antarctic Expedition 1971-73, and thanks the Department of Atomic Energy, Government of India and the Hydrometeorological Service of the USSR for allowing him to take part in the Expedition, and giving him the privilege of being the first Indian 
Explorer of Antarctica, which was made possible by the late Professor Vikram A. Sarabhai. The author is indebted to his father Sirdar Mohinder Singh Sehra and mother Shrimati Satwinder Kaur for having induced into him a deep-rooted love for scientific adventures and inspiring him to take part in the most venturesome Soviet Antarctic Expedition during 197173. The author is also greatly indebted to Professor P. R. Pisharoty for his stimulating guidance, kind encouragement and helpful discussions. The author expresses his sincere gratitude to the Hydrometeorological Service of the USSR for having awarded him the prestigeous Soviet Antarctic Medal and Soviet Antarctic Ribbon and for a unique souvenir of a special 24-hour Soviet Antarctic Watch especially made for the Polar Explorers, in recognition of his active participation in the Soviet Antarctic Expedition during 1971-73. The author now hopes to associate himself with the Japan Antarctic Research Programme and wishes to work at the Japanese Antarctic Station Showa sometime in future.

\section{References}

Groves, G. V., 1971: "Atmospheric structure and its variations in the region from 25 to $120 \mathrm{~km}$." Air Force Cambridge Research Laboratories Report No. AFCRL-71-0410, Bedford, Massachusetts, pp. 114, 130, 147.

Sehra, P. S., 1974: Upper mesospheric wind structure in Antarctica, Nature, 252, 683-686.

Sehra, P. S., 1975: Upper atmospheric thermal structure in Antarctica, Nature, 254, 401-404.

Webb, W. L. 1964: The dynamic stratosphere, Astronaut. Aeronaut., 2(3), 62-68.

\section{南極および赤道地域の大気の構造}

\section{Parmjit Singh Sehra}

(物理研究所, Ahmedabad, インド)

1972年の 1 月から 2 月（南半球の夏）にかけて南極の Molodezhanaya で行われた M-100 気象ロケットによる上 層大気の温度と風の観測結果を示し，同時期の南インドの Thumba でのものと比較した。また，Grovesのモデルと も比べてみた。夏の極域におけるトロポポーズおよびストラトポーズ温度は赤道域での対応する部分よりそれぞれ約 $170^{\circ} \mathrm{C}, 130^{\circ} \mathrm{C}$ 高温である。一方, メソポーズは極域の方が約 $250^{\circ} \mathrm{C}$ 冷い。両観測点之も成層圈の帯状流は東風で, 強さは 1 月には $50 \mathrm{~m} / \mathrm{s}$ 以下， 2 月には $35 \mathrm{~m} / \mathrm{s}$ 以下である。南北成分は変動が大きい。Groves モデルと比べてみる と，東西風速のずれは正負にわたって $35 \mathrm{~m} / \mathrm{s}$ 以内であるが，温度のずれは大体において負で $25{ }^{\circ} \mathrm{C}$ 程度である。 